\title{
Seagrass and epiphytic algae support nutrition of a fisheries species, Sillago schomburgkii, in adjacent intertidal habitats
}

\author{
Rod M. Connolly ${ }^{1,2, *}$, Jeremy S. Hindell ${ }^{3}$, Daniel Gorman ${ }^{1}$ \\ ${ }^{1}$ Centre for Aquatic Processes and Pollution, and School of Environmental and Applied Sciences, Griffith University, \\ PMB 50, Gold Coast Mail Centre, Queensland 9726, Australia \\ ${ }^{2}$ The Cooperative Research Centre for Coastal Zone, Estuary and Waterway Management, 80 Meiers Road, Indooroopilly, \\ Queensland 4068, Australia \\ ${ }^{3}$ Marine and Freshwater Systems, Primary Industries Research Victoria, Department of Primary Industries, PO Box 114, \\ Queenscliff, Victoria 3225, Australia
}

\begin{abstract}
The importance of organic matter produced in seagrass meadows (seagrass and epiphytic algae) to the nutrition of a valuable fisheries species (yellowfin whiting Sillago schomburgkii Peters) occurring over unvegetated mudflats was measured using the isotopic composition $\left(\delta^{13} \mathrm{C}\right.$, $\delta^{15} \mathrm{~N}$ ) of fish, their polychaete prey, and available autotrophic sources at several locations in southern Australia during 2 periods (summer, winter). Values for $\delta^{13} \mathrm{C}$ and $\delta^{15} \mathrm{~N}$ for autotrophs and fishes varied little between seasons. Sources could be separated into 3 groups based on $\delta^{13} \mathrm{C}$ : seagrass and epiphytes (mean $\delta^{13} \mathrm{C}=-10.5 \%$ ), benthic microalgae and macroalgae $(-19.5 \%$ ), and saltmarsh and mangroves $\left(-26.5 \%\right.$ o). Values of $\delta^{15} \mathrm{~N}$ for the sources were 2 to $5 \%$. Values of $\delta^{13} \mathrm{C}$ for fish $(-13.3 \%$ o) corresponded with those of their polychaete prey $(-12.5 \%)$ and ultimately with those of seagrass and epiphytes. Values of $\delta^{15} \mathrm{~N}$ were 5 to $6 \%$ more enriched than sources. Modelling of feasible source mixtures showed that seagrass and epiphytes were the most important contributors to the nutrition of fish, but their relative importance varied between seasons. The median contribution by other sources was $<10 \%$. Spatial analyses showed that saltmarsh plants contributed significantly to the variability in $S$. schomburgkii nutrition among locations, while macroalgae contributed in summer. The similarity in $\delta^{13} \mathrm{C}$ values of polychaetes and $S$. schomburgkii is consistent with source material from a subtidal habitat being incorporated into food webs supporting a fisheries species in adjacent intertidal habitats via a largely sedentary intermediary.
\end{abstract}

KEY WORDS: Posidonia · Mangrove · Saltmarsh · Algae · Sillaginidae · Diet · Trophic ecology Resale or republication not permitted without written consent of the publisher

\section{INTRODUCTION}

Determining the autotrophic sources supporting food webs leading to fisheries production is important for the purpose of conserving fisheries habitat. Animals in terrestrial systems ultimately obtain their nutrition from autotrophs alongside them (Polis et al. 1997). In marine systems, however, the role of water as a vector for energy (carbon) and nutrients means that autotrophic sources can potentially be spatially segregated from animals reliant on them (Carr et al. 2003).
In nearshore ecology, the focus has been on movement of organic matter from intertidal habitats to deeper waters (Odum 2000). There has been less emphasis on determining whether organic matter from subtidal habitats contributes to the nutrition of animals in adjacent, shallower habitats, although there is evidence of macrophyte contribution to sandy-beach food webs (Robertson \& Lenanton 1984).

Stable isotope analysis of carbon and nitrogen is an effective method for tracing the transfer of energy and nutrients from autotrophs to consumers, and has been 
used successfully for inshore fisheries species (e.g. Loneragan et al. 1997). The method relies on major categories of autotrophs having distinct ratios of rareto-common isotopes, which can be compared with ratios in consumer tissue to demonstrate the importance of a single source or combination of sources. In nearshore marine systems, the relatively large number of potential sources often makes it difficult to determine which sources are important. This problem can be overcome by combining 2 newly developed analytical methods. First, a model by Phillips \& Gregg (2003) calculates the range of plausible combinations of sources that explain the consumer's isotope value. Second, patterns of spatial variability in autotroph isotope values are correlated with those of a consumer; a significant correlation between an autotroph and, for example, a fish, implies that the autotroph makes an important contribution to the nutrition of the fish (Melville \& Connolly 2003).

Stable isotope studies have shown that fisheries species can rely on seagrass or their epiphytic algae as their ultimate source of nutrition (e.g. Lepoint et al. 2000, Moncreiff \& Sullivan 2001, Vizzini et al. 2002). Mangroves typically play only a minor role in the nutrition of fisheries species occurring outside mangrove forests (Bouillon et al. 2002), although no studies involving mangroves have previously been done in temperate waters. Although saltmarsh grasses can be an important source of energy for marsh consumers in the USA (Peterson \& Howarth 1987, Currin et al. 1995), Australian saltmarshes are positioned higher in the intertidal zone and are inundated less frequently, and there is little evidence that marsh plants in Australia contribute to marine food webs. Microalgae on the mudflats have, however, been shown to contribute to fisheries species in subtropical Australian waters (Melville \& Connolly 2003), and the importance of microalgae to meiofauna has been demonstrated in Europe (Middelburg et al. 2000). In many sheltered embayments, macroalgae are a conspicuous floral element, but the importance of this source in the nutrition of fishes has only been shown on rocky reefs (Jennings et al. 1997).

The movement of energy and nutrients from one habitat to another can occur via movement of detrital organic matter in the water column or movement of prey species (Kneib 2000). Examining isotope values of key prey species of higher-order consumers can potentially separate the importance of these alternative mechanisms. Few isotope studies provide clear evidence for pathways of organic matter among nearshore habitats, but one that does so is that by Klumpp \& Nichols (1983) on the large, predatory rock flathead Platycephalus laevigatus in seagrass meadows.
Sillaginid fishes are found in shallow waters along much of the Australian coastline, and represent one of the most widespread inshore families important to fisheries. Sillago schomburgkii is an important commercial and recreational fisheries species in the states of South Australia and Western Australia (Kailola et al. 1993). Landings in the commercial gill and seine net fisheries in South Australia have been up to $200 \mathrm{t}$ per annum historically, but more recently are about $150 \mathrm{t}$ (Knight et al. 2003). S. schomburgkii is probably more important in the recreational fishery, with a current value that is at least equal to, but probably greater than, the commercial value (McGlennon \& Branden 1994). No study has attempted to link $S$. schomburgkii with the ultimate autotrophic source of nutrition at the base of the food web leading to production of this carnivorous fisheries species.

In the upper parts of the South Australian gulfs, several autotrophs potentially provide organic material to food webs that support valuable fisheries. The most conspicuous sources are seagrasses and their associated algal epiphytes, mangroves, and saltmarsh plants. The intertidal mudflats also contain microalgae. For several years, government bodies in Australia have been planning a series of marine protected areas to conserve habitat capable of supporting marine animal resources (Stevens 2002). Managers are aware that they need to protect not only the habitat in which animals occur, but also other, separate, habitats from which autotrophic production contributes to food webs. Unfortunately, there is no evidence of the autotrophic sources of nutrition for fisheries species in South Australia, including sillaginids such as Sillago schomburgkii.

The aims of the current study were to (1) determine the autotrophic source(s) contributing to the base of food webs providing nutritional support for Sillago schomburgkii, and (2) use isotope values of key prey types to understand the mechanism by which organic matter moves among habitats.

\section{MATERIALS AND METHODS}

Study species. Yellowfin whiting Sillago schomburgkii Peters occurs in the temperate waters of southern and western Australia (Kailola et al. 1993). It is an estuarine opportunist, spawning in open waters but occurring as juveniles and adults in gulfs and sheltered bays (Potter \& Hyndes 1999). In South Australian waters, S. schomburgkii is restricted to the upper regions of Spencer Gulf and Gulf St. Vincent (Fig. 1), where the water is typically warmer and more saline than exposed marine waters at the same latitude (Noye 1984). Spawning occurs predominantly in summer, and 


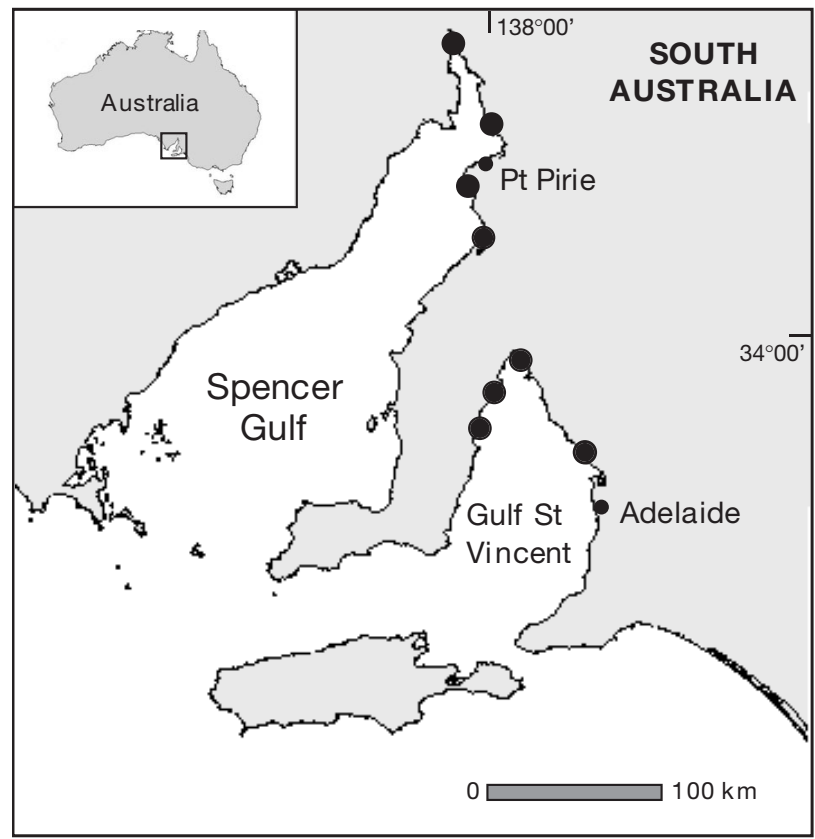

Fig. 1. South Australian gulfs, showing 8 sampling locations. Inset: location of study region in Australia

fish reach maturity and enter the fishery at around $20 \mathrm{~cm}$ length and after about $2 \mathrm{yr}$. Although the typical maximum size of $35 \mathrm{~cm}$ is not large for sillaginids, growth is fast relative to that of congeneric species caught in the same regions (Hyndes \& Potter 1997).

Sillago schomburgkii inhabits sheltered, shallow waters supporting large areas of seagrass, mangroves, saltmarsh and unvegetated intertidal flats (Bryars 2003). The highest densities of S. schomburgkii have been recorded in tidal creeks surrounded by extensive stands of mangroves and saltmarsh (Connolly \& Jones 1996). It sometimes occurs over seagrass, but is more common over unvegetated habitat (Connolly 1994). S. schomburgkii in Western Australia is carnivorous, feeding on a range of benthic crustaceans, polychaete worms and bivalves (Hyndes et al. 1997).

Sample collection and processing. The upper sections of the gulfs of South Australia are fringed by substantial stands of mangroves. Saltmarsh is common on the landward side of mangroves. Mudflats without conspicuous vegetation extend up to $200 \mathrm{~m}$ seaward of the mangroves to a narrow band of intertidal seagrass and extensive subtidal meadows of seagrass. Autotrophs and Sillago schomburgkii were collected twice, once in austral winter (June 2002) and once in austral summer (January 2003), at eight locations along approximately $200 \mathrm{~km}$ of coastline (Fig. 1). These 2 periods were not used in an attempt to represent seasons per se but to obtain data at more than one time. All samples were frozen immediately upon collection.
We attempted to sample Sillago schomburgkii from a range of inshore habitats using gill, seine and trawl nets at different tidal stages, but the fish could only be caught over mudflats adjacent to mangroves or in the mouths of mangrove-lined creeks. We collected 3 fish at both periods from every location, except at 2 locations in winter where no fish could be caught. At 1 location, 9 fish were collected to determine any relationship between fish length and isotope values. When more than the required number of fish was caught, we selected fish of a length most commonly found at that period. Selected fish ranged from 8 to $30 \mathrm{~cm}$ in winter and 14 to $35 \mathrm{~cm}$ in summer.

Except where otherwise noted, 3 samples of the following autotrophs were collected from every location at both collection times. On the saltmarsh, leaves were collected from the 2 most abundant species, bearded glasswort Sarcocornia quinqueflora and grey samphire Halosarcia halocnemoides. Isotope values from the 2 species were similar to each other at both times $(<1.2 \%$ difference for $\mathrm{C}$ and $\mathrm{N}$ at each site) and were therefore pooled. Green leaves were collected from the single species of mangrove that occurs in South Australia, the grey mangrove Avicennia marina. We collected 2 types of seagrass: eelgrass Zostera mucronata at the bottom of the intertidal zone, and strapweeds Posidonia australis or P. sinuosa subtidally. Isotope values from the 2 types were similar to each other at both times ( $<1.5 \%$ difference for $\mathrm{C}$ and $\mathrm{N}$ at each site) and were therefore pooled. Seagrass epiphytes consisting of diatoms and fine, filamentous algae were separated from seagrass in the laboratory by scraping with a scalpel (Guest et al. 2004). Enough epiphyte material for isotope analysis was obtained from every location in the summer but from only 5 locations in winter. Macroalgae were never common at any location, probably because of the lack of hard substratum in the upper parts of the gulfs, but at some locations macroalgae were found attached to shells and small rocks in sufficient quantity to collect a sample. Macroalgal samples consisted of red algae (predominantly Laurencia spp.) in winter and brown algae (Cystophora spp.) in summer.

Microalgal and cyanobacterial cells, collectively known as microphytobenthos, were collected by scraping the surface $1 \mathrm{~cm}$ of sediment from mudflats near locations of fish collections. Sediment was washed through $53 \mu \mathrm{m}$ mesh to remove infauna. Material passing through the mesh was then washed through $5 \mu \mathrm{m}$ mesh. Material retained on this mesh was added to a centrifuge tube containing colloidal silica (LUDOX ${ }^{\mathrm{TM}}$, density $=1.21$ ) and centrifuged at $12100 \times g$ for $10 \mathrm{~min}$. A band of diatoms, some organic matter and silica particles formed at the top of the centrifuge tube. This band was removed and again washed through 
a $5 \mu \mathrm{m}$ mesh to remove the silica and any remaining microbes. Inspection of samples showed that they consisted predominantly of microalgae (mainly diatoms) with occasional contamination by very fine detrital fragments.

Phytoplankton densities were very low relative to the high load of particulate detrital material in the water at our locations. We were therefore unable to process samples of suspended particulate matter to obtain a phytoplankton sample pure enough to represent this autotroph. Instead we filtered seawater to obtain a measure of the isotope signature of suspended particulate matter (seston).

All samples were dried to constant weight at $60^{\circ} \mathrm{C}$, ground to a powder, placed in tin capsules and analysed on an Isoprime isotope-ratio mass spectrometer. The ratios of ${ }^{15} \mathrm{~N} /{ }^{14} \mathrm{~N}$ and ${ }^{13} \mathrm{C} /{ }^{12} \mathrm{C}$ were expressed as the relative per mille (\%) difference between the sample and conventional standards (air for nitrogen; PeeDee belemnite limestone carbonate for carbon).

Modelling feasible source mixtures to explain fish nutrition. Autotrophs were pooled into 6 taxa: saltmarsh, mangroves, seagrass, epiphytic algae, microphytobenthos and macroalgae. Mean $\delta^{13} \mathrm{C}$ values were calculated for Sillago schomburgkii and each autotroph taxon across all locations, separately for the 2 periods. We used these mean values in the isosource model of Phillips \& Gregg (2003) to calculate feasible combinations of autotrophs that could explain the consumer signature. This method examines all possible combinations of each autotroph potential contribution (0 to $100 \%$ ) in small increments (here 1\%). Combinations that added to within $0.01 \%$ of the consumer signature were considered feasible solutions. ${ }^{15} \mathrm{~N}$ was not used in the modelling because of sensitivity to fractionation corrections (see next paragraph). Results are reported as the distribution of feasible solutions for each autotroph. We also give the median contribution and the 1 and 99 percentile range rather than the full range, which is sensitive to small numbers of observations on the tails of the distribution (Phillips \& Gregg 2003).

Previous studies have shown that nitrogen isotopes in organisms are enriched relative to the organisms ${ }^{\prime}$ diet (e.g. Peterson \& Fry 1987). This fractionation is much larger for ${ }^{15} \mathrm{~N}$ than for ${ }^{13} \mathrm{C}$, hence nitrogen isotopes can provide useful information about the trophic level of animals and the food web structure. For modelling of feasible mixtures, however, $\delta^{15} \mathrm{~N}$ values of consumers must be corrected for fractionation. We initially included $\delta^{15} \mathrm{~N}$ in our modelling using a fractionation correction based on the most recently reported average fractionation increase of $2.2 \%$ per trophic level (McCutchan et al. 2003). However, we could not be confident that this fractionation rate applied to Sillago schomburgkii. The fractionation rate per trophic level is known to vary considerably with animal age, growth rates and food quality (Vander Zanden \& Rasmussen 2001), and we had no information about how these factors affected fractionation in S. schomburgkii. When we ran the model using C and $\mathrm{N}$ data, we found that results varied substantially if we changed our corrected $\delta^{15} \mathrm{~N}$ value by even a small amount (Table 1). We decided that using $\mathrm{N}$ was unhelpful in feasibility modelling, although we retained it for spatial modelling (see next subsection).

Table 1. Sensitivity of isosource modelling to changed assumptions about fractionation of isotope values across trophic levels. Values are median contributions of each autotroph to S. schomburgkii nutrition. Assumed fractionation is either our estimate of the most likely actual rate ('target', being 0 for $\mathrm{C}$ and $2.2 \%$ per trophic level for $\mathrm{N}$ ) or $\pm 1 \%$ from the target value. $\mathrm{C}$ modelling used only this element; $\mathrm{N}$ modelling used both elements, and the target value for $\mathrm{C}$ was used. Where no value is given, the corrected value for $S$. schomburgkii lay outside the polygon of autotrophs and no feasible solutions were possible. MPB: microphytobenthos

\begin{tabular}{|c|c|c|c|c|c|c|c|}
\hline \multirow{2}{*}{ Season } & \multirow{2}{*}{$\begin{array}{c}\text { Assumed } \\
\text { fractionation }\end{array}$} & \multirow[b]{2}{*}{ Epiphytes } & \multirow[b]{2}{*}{ Macroalgae } & \multicolumn{2}{|c|}{ Autotroph contribution (\%) } & \multirow[b]{2}{*}{ Saltmarsh } & \multirow[b]{2}{*}{ Seagrass } \\
\hline & & & & Mangroves & MPB & & \\
\hline \multicolumn{8}{|l|}{ Carbon } \\
\hline \multirow[t]{3}{*}{ Winter } & -1 & 20 & 5 & 2 & 4 & 2 & 62 \\
\hline & target & 25 & 7 & 3 & 6 & 3 & 49 \\
\hline & +1 & 27 & 9 & 5 & 8 & 5 & 40 \\
\hline \multirow[t]{3}{*}{ Summer } & -1 & 48 & 6 & 3 & 6 & 4 & 27 \\
\hline & target & 40 & 8 & 5 & 8 & 5 & 28 \\
\hline & +1 & 33 & 10 & 6 & 10 & 6 & 27 \\
\hline \multicolumn{8}{|l|}{ Nitrogen } \\
\hline \multirow[t]{3}{*}{ Winter } & -1 & - & - & - & - & - & - \\
\hline & target & 81 & 6 & 2 & 2 & 2 & 4 \\
\hline & +1 & 33 & 8 & 3 & 5 & 3 & 44 \\
\hline \multirow[t]{3}{*}{ Summer } & -1 & - & - & - & - & - & - \\
\hline & target & 61 & 18 & 3 & 5 & 8 & 2 \\
\hline & +1 & 26 & 7 & 4 & 8 & 4 & 45 \\
\hline
\end{tabular}


Fractionation in $\delta^{13} \mathrm{C}$ is relatively minor, typically $<1 \%$ o per trophic level (McCutchan et al. 2003). We therefore used no correction for fractionation for $\delta^{13} \mathrm{C}$. Nevertheless, to test the sensitivity of the model to small fractionation shifts in $\delta^{13} \mathrm{C}$, as well as running the model using the mean $\delta^{13} \mathrm{C}$ value, we re-ran it using adjusted $\delta^{13} \mathrm{C}$ values, both adding and subtracting $1 \%$ to the mean Sillago schomburgkii value. The results were less affected by these adjustments than by those for nitrogen, and the rank order of autotroph contributions was not affected (Table 1).

Spatial analysis to detect nutrition sources for fish. We used the 2-element spatial correlation procedure of Melville \& Connolly (2003) to test whether Sillago schomburgkii showed the same pattern of spatial variability as any of the autotrophs. Mean isotope values were calculated for S. schomburgkii and each autotroph taxon at each location, separately for summer and winter. Using $\delta^{13} \mathrm{C}$ and $\delta^{15} \mathrm{~N}$ signatures as Cartesian coordinates, Euclidean distances were calculated between the value for S. schomburgkii and an autotroph taxon at all locations at which they both occurred. These distances (D) were averaged to produce a measure of correlation in 2-dimensional space. To obtain a distribution of potential fish/autotroph distances, location labels of autotrophs were changed in every possible permutation, and Euclidean distances were recalculated. A probabilistic test of significance was generated by comparing the observed D of the fish/autotroph combination to this distribution of possible D values. If the $\mathrm{D}$ value was small relative to the distribution of possible values, then values of S. schomburgkii were spatially correlated with that particular autotroph.

As Melville \& Connolly (2003) pointed out, where isotope values of more than 1 autotroph are spatially correlated with consumer values, this might be because the autotrophs themselves are correlated. When we found more than 1 autotroph correlated with fish values, we used the test procedure described above to test whether values for those autotrophs were correlated in space.

For spatial analyses, no correction for fractionation according to trophic level is necessary, since the offset between fish and autotroph values does not affect the test of spatial correlations (Melville \& Connolly 2003). However, if there is a relationship between fish lengths and isotope values, then that relationship can be used to adjust fish values to provide new values standardised for length. The relationships between length of Sillago schomburgkii and isotope values were tested using regression analysis on carbon and nitrogen separately, in winter and summer. These fish were from a single location, where additional fish had been collected for this purpose, thus avoiding confounding with spatial differences. Where a significant relationship existed, raw stable isotope values were adjusted for length using the formula from Melville \& Connolly (2003):

$$
\delta X^{\prime}=\delta X-(a \cdot F L)
$$

where $\delta X^{\prime}$ is the adjusted isotope signature, $\delta X$ is the raw isotope value, $a$ is a regression coefficient and FL is the fork length of fish (mm). The only significant relationship was for carbon in winter $\left(\delta^{13} \mathrm{C}=0.08 \mathrm{FL}-\right.$ $\left.21.0 ; \mathrm{r}^{2}=0.83 ; \mathrm{p}=0.012\right) . \delta^{13} \mathrm{C}$ values of $S$. schomburgkii were therefore adjusted using the equation above $(a=0.08)$ prior to the spatial analysis.

Isotope values of dominant prey type. To assess whether the base for nutritional support of the dominant prey item was consistent with Sillago schomburgkii, we first had to identify which prey were most common. The major prey types of S. schomburgkii were identified by examining the stomach contents of fish collected for isotope analysis in the first sampling period in this study (winter). The dominant prey item in every fish examined was errant polychaete worms, which comprised 75 to $100 \%$ of prey items by number. We collected errant polychaetes from the wild at 4 locations by sieving superficial sediment from mudflats where S. schomburgkii had been caught. As near as practicable to 10 polychaetes of an equal mix from the families Nereididae and Nephtyidae were retained from each location (total $\mathrm{n}=38$ ); these were washed and then processed as for fish tissue (above). The isosource model was used on mean $\delta^{13} \mathrm{C}$ prey values following the same procedure as for fish.

\section{RESULTS}

\section{Autotroph and fish isotope values}

In both winter and summer, autotrophs fell into 3 groups based on $\delta^{13} \mathrm{C}$ signatures: (1) enriched sources of seagrass and its epiphytic algae; (2) sources with intermediate values, consisting of MPB and macroalgae; (3) depleted sources of saltmarsh and mangroves (Fig. 2). Seagrass had the most depleted $\delta^{15} \mathrm{~N}$ signatures in both seasons (at $<2 \%$ ) and other autotrophs ranged up to about $5 \%$ (Fig. 2).

Mean $\delta^{13} \mathrm{C}$ values for seston were very enriched $(-11.6$ and $-12.3 \%$ in winter and summer, respectively) and mean $\delta^{15} \mathrm{~N}$ values were towards the upper end of the range for autotrophs (5.2 and $4.0 \%$ ).

Isotope values for Sillago schomburgkii were similar in both seasons (Fig. 2). $\delta^{13} \mathrm{C}$ values for S. schomburgkii were towards the enriched end of the range for autotrophs; $\delta^{15} \mathrm{~N}$ values were 5 to $6 \%$ more enriched than the most enriched autotroph value (Fig. 2). 

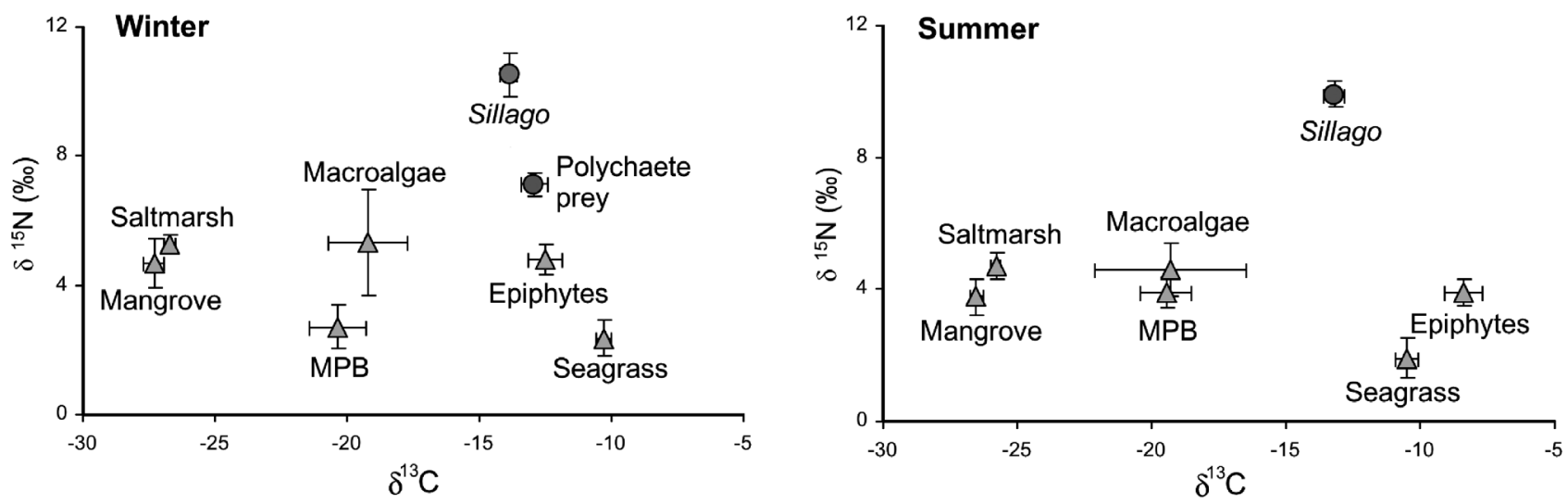

Fig. 2. Plots of $\delta^{13} \mathrm{C}$ and $\delta^{15} \mathrm{~N}$ values (mean $\pm \mathrm{SE}$ ) for Sillago schomburgkii and 6 autotroph sources in winter and summer, and for polychaete prey (winter only). MPB: microphytobenthos

\section{Feasible source mixtures explaining fish nutrition}

In both seasons, 2 autotrophs (seagrass and epiphytes) were the most likely contributors to Sillago schomburgkii nutrition. Taking into account the shape of the distribution plot, the 1 to 99 percentile range, and the median feasible contribution, seagrass was the most likely contributor to fish nutrition in winter (median contribution 49\%), followed by epiphytic algae (25\%, Fig. 3). The relative contribution of these autotrophs was reversed in summer, when epiphytic algae had the highest likelihood of contributing to S. schomburgkii $(40 \%)$, with seagrass potentially contributing $28 \%$. The other autotrophs (mangrove/ saltmarsh and macroalgae/microphytobenthos) had a low likelihood of making a substantial contribution to S. schomburgkii nutrition. The median contribution over all feasible mixtures for these other autotrophs was always less than $10 \%$. The maximum contribution (99 percentile) that one of these other autotrophs could have made was 15 to $29 \%$ in winter and 20 to $33 \%$ in summer (Fig. 3).

\section{Nutrition sources for fish detected by spatial analysis}

Seagrass was the only autotroph whose values of $\delta^{13} \mathrm{C}$ and $\delta^{15} \mathrm{~N}$ varied significantly with those of Sillago schomburgkii across sites in both seasons (Table 2). In winter, 2 of the 6 autotrophs (seagrass and saltmarsh) were correlated with $S$. schomburgkii. The values of these 2 autotrophs were not themselves correlated in space (Table 3). Both autotrophs are therefore independently correlated with $S$. schomburgkii, implying a substantial contribution of each to fish nutrition. Note that, in winter, epiphyte values could not be tested against $S$. schomburgkii values because the number of locations where this autotroph and S. schomburgkii were both collected was too low $(n=3)$.

In summer, 3 autotrophs (macroalgae, epiphytes and seagrass) were correlated with Sillago schomburgkii (Table 2). In tests of correlations among the autotrophs, epiphytes were correlated with macroalgae and seagrass, but macroalgae and seagrass were not correlated (Table 3). The relationship between seagrass and $S$. schomburgkii values at different locations is given in Fig. 4 as an example of how the patterns correlate in 2-dimensional space (i.e. the relative positions of values at different sites are similar for fish and seagrass).

Table 2. Results of permutation tests for correlations in 2dimensional space (2 elements) between Sillago schomburgkii and autotrophs. D: average Euclidean distance between fish and autotroph values at each location; $\mathrm{p}$ : proportion of D values observed D (significant values in bold). Number of joint locations for S. schomburgkii and epiphytes was too low to make a useful test in winter

\begin{tabular}{|lcrrc|}
\hline Autotroph & $\begin{array}{c}\text { No. of } \\
\text { locations }\end{array}$ & Permutations & Observed D & $\mathrm{p}$ \\
\hline Winter & & & & \\
Epiphytes & 3 & 6 & - & - \\
Macroalgae & 4 & 24 & 14.3 & 0.083 \\
Mangrove & 5 & 120 & 9.8 & 0.850 \\
MPB & 5 & 120 & 18.6 & 0.475 \\
Saltmarsh & 6 & 720 & 8.7 & $\mathbf{0 . 0 2 8}$ \\
Seagrass & 6 & 720 & 21.3 & $\mathbf{0 . 0 4 6}$ \\
Summer & & & & \\
Epiphytes & 8 & 40320 & 7.5 & $\mathbf{0 . 0 2 0}$ \\
Macroalgae & 7 & 5040 & 8.6 & $\mathbf{0 . 0 0 1}$ \\
Mangrove & 8 & 40320 & 15.0 & 0.699 \\
MPB & 8 & 40320 & 9.0 & 0.545 \\
Saltmarsh & 8 & 40320 & 13.8 & 0.459 \\
Seagrass & 8 & 40320 & 8.1 & $\mathbf{0 . 0 2 8}$ \\
\hline
\end{tabular}



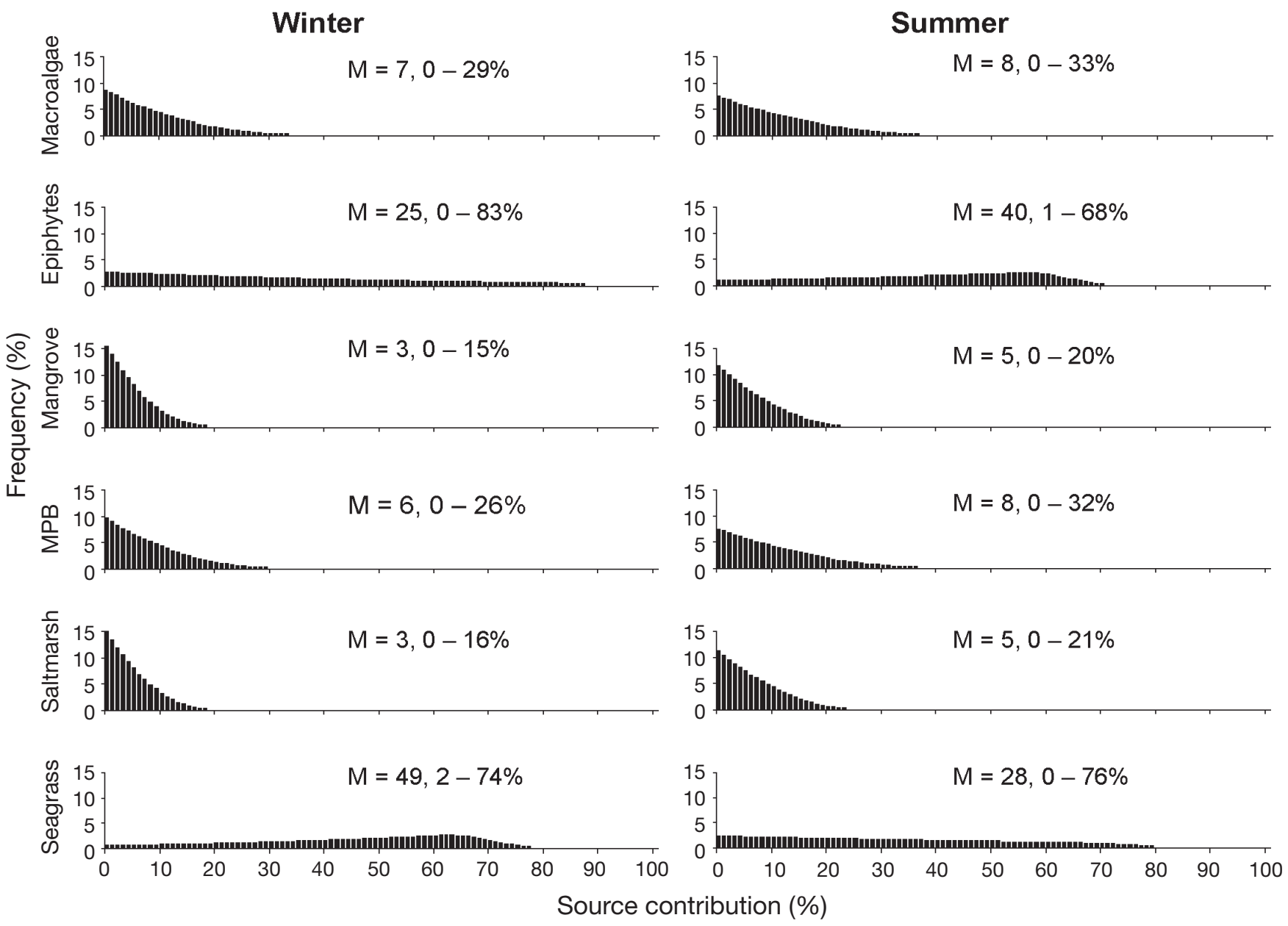

Fig. 3. Distributions of feasible contributions of 6 autotrophs to nutrition of Sillago schomburgkii based on $\delta^{13} \mathrm{C}$ values only. M: median; ranges: 1 and 99 percentiles. MPB: microphytobenthos

\section{Isotope values of dominant prey type}

$\delta^{13} \mathrm{C}$ values of polychaete worms were highly enriched (mean $=-12.5 \%$, $\mathrm{SE}=0.2$ ) and very similar to values for Sillago schomburgkii (Fig. 2). As for fish, feasibility modelling showed that seagrass and epiphytes were the most likely sources of nutrition for polychaetes (median contributions 47 and $28 \%$, respectively). All other autotrophs had very low feasible contributions. $\delta^{15} \mathrm{~N}$ values of polychaetes were intermediate between those of autotrophs and $S$. schomburgkii (Fig. 2, mean $=7.0 \%$, $\mathrm{SE}=0.1$ ).
Table 3. Results of permutation tests for correlations in 2-dimensional space (2 elements) among autotrophs that showed a relationship with Sillago schomburgkii. D: average Euclidean distance between autotroph values at each location; p: proportion of D values $\leq$ observed D (significant values in bold)

\begin{tabular}{|lcccc|}
\hline Autotroph pair & $\begin{array}{c}\text { No. of } \\
\text { locations }\end{array}$ & Permutations & Observed D & $\mathrm{p}$ \\
\hline Winter & & 40320 & 17.1 & 0.319 \\
Saltmarsh vs seagrass & 8 & & & \\
Summer & & 40320 & 7.5 & $\mathbf{0 . 0 1 8}$ \\
Epiphytes vs macroalgae & 8 & 40320 & 15.0 & $\mathbf{0 . 0 0 2}$ \\
Epiphytes vs seagrass & 8 & 5040 & 8.8 & 0.076 \\
Macroalgae vs seagrass & 7 & & & \\
\hline
\end{tabular}

\section{DISCUSSION}

\section{Sources of nutrition for fish}

Ultimate sources of nutrition for Sillago schomburgkii are predominantly seagrass and algae epiphytic on seagrass. This overwhelming contribution of organic material originating from seagrass meadows was consistent across the 2 periods examined. The relative contributions of seagrass and 


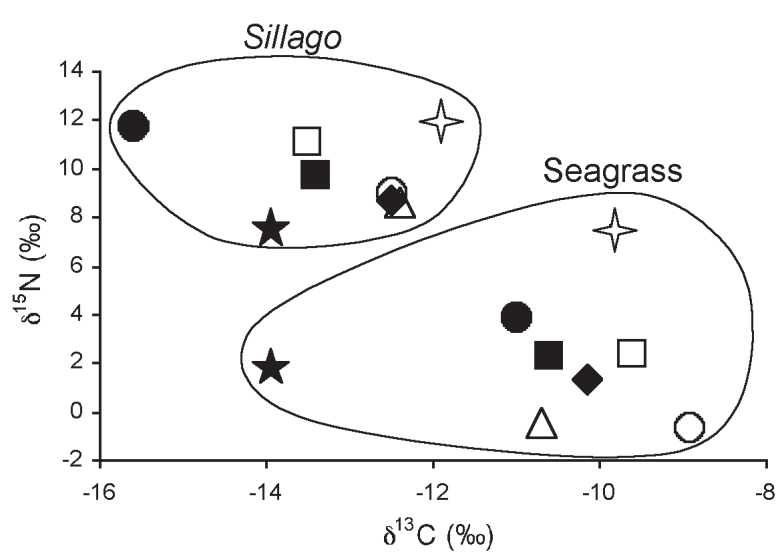

Fig. 4. Example of correlation in 2-dimensional space. $\delta^{13} \mathrm{C}$ and $\delta^{15} \mathrm{~N}$ values for Sillago schomburgkii and seagrass at each location in summer (symbols are the same for the same site across autotroph and fish)

epiphytic algae varied through time, with seagrass dominant in the winter period and epiphytes in the summer. We did not test whether this is a seasonal phenomenon: this test would require data from the 2 seasons over a number of years. Previous studies examining the contribution of seagrass and epiphytes to animals living in seagrass meadows reported that seagrass and/or epiphytes are ultimately the main source of nutrition (e.g. Moncreiff \& Sullivan 2001). It has also been shown that seagrass meadows produce far more organic matter than can be utilised by consumers living in the meadows (Duarte \& Cebrian 1996); therefore, excess production is potentially available for use in detrital food webs in adjacent habitats.

Feasibility modelling of source mixtures did not help to distinguish among autotrophs other than seagrass or epiphytes, but demonstrated that their combined contribution was relatively minor. Spatial analyses highlighted the role of one of these other autotrophs, but not the same one, in both seasons. In winter, isotope values of Sillago schomburgkii were significantly correlated with saltmarshes, which suggests that at least some of the variability in nutrition of fish between sites was driven by saltmarshes. In summer, however, $S$. schomburgkii isotope values were correlated with those of macroalgae, seagrass and epiphytes. Since macroalgae and seagrass values were themselves correlated with epiphytes, we cannot distinguish between 2 possible scenarios to explain the relative importance of sources to the nutrition of S. schomburgkii in summer. First, contributions of each of the 3 autotrophs to S. schomburgkii nutrition may have been so substantial as to result in S. schomburgkii values tracking the autotroph values from location to location. Alternatively, either seagrass and macroalgae or both might have been correlated with $S$. schomburgkii only be- cause they happened to show the same pattern of spatial variability as epiphytes. The importance of seagrass was established with the feasibility modelling, so it is the contribution of macroalgae that is in question. We cannot establish beyond doubt the role of macroalgae, but it remains the most likely of the alternative autotrophs to have contributed to $S$. schomburgkii nutrition in the summer.

Taking into account modelling of sources and spatial analyses, the most likely scenario in winter is that seagrass was the dominant source followed by epiphytes, together contributing in the order of $80 \%$ of nutrition, with saltmarsh the largest component of the remainder (perhaps 10\%). In summer, epiphytes exceeded seagrass in importance, and macroalgae replaced saltmarshes as the largest contributor of the alternative autotrophs.

A review of studies of mangrove contributions to food webs in other habitats found little evidence of mangroves being important, despite conspicuous production of mangrove leaf material and the widely held view that outwelled mangrove detritus supports species in subtidal habitats (Lee 1995). The present study provides the first test of the role of mangroves in food webs in temperate waters and shows that mangroves contribute little to the nutrition of Sillago schomburgkii. Given that we were able to catch $S$. schomburgkii only alongside mangroves in this study, and that their highest densities in South Australia have been recorded from mangrove-lined creeks (Connolly \& Jones 1996), we consider this species to be more likely than most to show a reliance on mangrove material. That it did not do so suggests that any importance of mangroves in food webs is limited to consumers actually resident in the mangrove forests rather than to consumers having merely a loose association with the forests. Furthermore, the significant contribution of material from adjacent seagrass systems (seagrass and epiphytes) is consistent with the movement of subtidal material into intertidal regions.

The role of saltmarsh plants in the nutrition of Sillago schomburgkii, while relatively minor, is the first demonstration in Australia of a contribution of saltmarsh material to the nutrition of fishes. The importance of saltmarsh organic material to consumers occurring in adjacent habitats has been well established for marshes along the east coast of North America (Peterson \& Howarth 1987, Currin et al. 1995). The only previous suggestion of a trophic role for Australian saltmarshes was the possible contribution of salt couch grass Sporobolus virginicus to Sillago ciliata in subtropical waters of southeast Queensland (Melville \& Connolly 2003). The importance of salt couch grass was unable to be confirmed in that study, however, because salt couch grass has a carbon isotope value similar to seagrass, and consequently its contribution to food webs could not be separated from that of seagrass. 


\section{Energy and nutrient pathways from autotrophs to fish}

Sillago schomburgkii relies mainly on material from seagrass meadows even though it occurs predominantly over unvegetated mudflats in close proximity to mangroves. Our present results show some similarities with those of a previous study into the nutrition of fishes occurring in habitats adjacent to seagrass meadows (Melville \& Connolly 2003). That study, in the subtropical waters of southeast Queensland, Australia, included a sillaginid fish $S$. ciliata that occurs mainly over unvegetated mudflats (Gray et al. 1996). Although S. ciliata derives some nutrition from benthic microalgae in the sediment, organic matter from seagrass and epiphytic algae in adjacent meadows is also a major source of nutrition (Melville \& Connolly 2003).

The isotope values we recorded for the key prey type (polychaete worms) and for seston give insights into the likely pathway of organic material moving from seagrass meadows to fishes. Movement of carbon and nutrients can occur either via movement of particulate or dissolved matter in the water column and/or via trophic relay - the movement of prey from one habitat to another (Kneib 2000). In the case of Sillago schomburgkii caught over mudflats, there are 2 lines of evidence that support the former of these possibilities. First, the main prey item of $S$. schomburgkii, polychaete worms, are found on mudflats between the extensive seagrass meadows and mangrove forests, and have carbon isotope values consistent with seagrass/epiphyte material as a nutrition source. Although the diet and behaviour of these worms are not well described, the families are generally considered to be detritivorous (Nereididae) or carnivorous (Nephtyidae). We cannot discount the possibility that the worms had visited seagrass meadows in the period preceding sampling, but it is more likely that they feed on the mudflats on which they were caught. Second, seston values show that particulate organic matter in the water column is dominated by material with enriched carbon isotope values, presumably either seagrass and/or epiphytic algae. It seems that the invertebrate prey types consumed by $S$. schomburgkii rely on organic material from seagrass meadows even when they occur outside the meadows. This organic material is abundant in the water column, and the simplest model is that seagrass and epiphytic algal material is borne on currents to adjacent habitats where it is consumed by detritivorous invertebrates, and thus to carnivorous invertebrates, both of which are consumed by fishes. This is an example of movement of energy and nutrients from subtidal to intertidal habitats, and the polychaete assemblage provides an avenue for organic material from seagrass meadows to ultimately support production of $S$. schomburgkii.
Separating contributions of seagrass and epiphytes

The relative contribution of macrophytes versus epiphytic algae has been the subject of long-standing debate in freshwater (Boon \& Bunn 1994) and estuarine (Moncreiff \& Sullivan 2001) systems. In studies on the contribution of seagrass and epiphytic algae to animals living in seagrass meadows, results have either been inconclusive, or have shown that epiphytes are important (Moncreiff \& Sullivan 2001). Our study is exceptional in that it provides evidence of some contribution of seagrass itself, in this case to a consumer living in adjacent areas. Similarity of carbon isotope values of seagrass and epiphytes, as found in the current study, frequently prevents studies from distinguishing between these 2 sources. Further work will be needed in South Australia to achieve tighter resolution of the relative contributions of seagrass and epiphytes to the nutrition of Sillago schomburgkii. Attempts to circumvent this problem were made by Kitting et al. (1984) to examine spatial variation in the 2 autotrophs and compare this with variation in a consumer (a shrimp) using graphical means. This work was the precursor to the more rigorous statistical testing of spatial correlations developed by Melville \& Connolly (2003). Moncreiff \& Sullivan (2001) successfully employed sulphur isotopes to separate the contribution of epiphytes and seagrass to consumers in seagrass meadows, and this is a technique offering more promise, as sulphur isotope-analysis becomes more routine (Fry et al. 2002, Connolly et al. 2004, Oakes \& Connolly 2004). Another technique showing promise is the potential to separate nitrogen isotope values of seagrass and epiphytes in manipulative experiments (Winning et al. 1999, Mutchler et al. 2004).

\section{Implications for conservation of coastal habitats}

This study provides evidence of the importance of organic material from seagrass meadows as the base for nutrition of a fisheries species of commercial and recreational importance. It describes a clear case of segregation between the habitats in which the fish occur and those from which they obtain the majority of their ultimate nutrition source. The usual assumption is of movement of organic material from shallower to deeper waters, but the opposite appears to apply for Sillago schomburgkii. Organic material from subtidal seagrass meadows is important to this species, which spends much of its time and consumes much of its prey (polychaetes) over intertidal habitats inshore of the seagrass. In considering a system of marine protected areas, not only in South Australia (Edyvane 1999) but also in other regions of the world, this trophic link 
between seagrass and the animals occurring in adjacent coastal habitats must be taken into account. Our study provides an example of the need to understand and account for trophic links between nearshore habitats in designing marine protected areas.

Acknowledgements. We thank K. Preston and E. Clarke for assistance with collection, processing and analysis, and R. Diocares for mass spectrometry. S. Bryars assisted with fisheries habitat maps, and S. Murray-Jones with MPA policies. We also thank J. Oakes for constructive comments on the manuscript. The Fisheries Research and Development Corporation supported this work.

\section{LITERATURE CITED}

Boon PI, Bunn SE (1994) Variations in the stable isotope composition of aquatic plants and their implications for food web analysis. Aquat Bot 48:99-108

Bouillon S, Raman AV, Dauby P, Dehairs F (2002) Carbon and nitrogen stable isotope ratios of subtidal benthic invertebrates in an estuarine mangrove ecosystem (Andhra Pradesh, India). Estuar Coast Shelf Sci 54:901-913

Bryars S (2003) An inventory of important coastal fisheries habitats in South Australia. Primary Industries and Resources South Australia, Adelaide

Carr M, Neigel J, Estes J, Andelman S, Warner R, Largier J (2003) Comparing marine and terrestrial ecosystems: implications for the design of coastal marine reserves. Ecol Appl 13:90-107

Connolly RM (1994) A comparison of fish assemblages from seagrass and unvegetated areas of a southern Australian estuary. Aust J Mar Freshw Res 45:1033-1044

Connolly RM, Jones GK (1996) Determining effects of an oil spill on fish communities in a mangrove-seagrass ecosystem in southern Australia. Aust J Ecotox 2:3-15

Connolly RM, Guest MA, Melville AJ, Oakes JM (2004) Sulphur stable isotopes separate producers in marine foodweb analysis. Oecologia 138:161-167

Currin CA, Newell SY, Paerl HW (1995) The role of standing dead Spartina alterniflora and benthic microalgae in salt marsh food webs: considerations based on multiple stable isotope analysis. Mar Ecol Prog Ser 121:99-116

Duarte CM, Cebrian J (1996) The fate of marine autotroph production. Limnol Oceanogr 41:1758-1766

Edyvane KS (1999) Conserving marine biodiversity in South Australia. Part 1. Background, status and review of approach to marine biodiversity conservation in South Australia, South Australian Research and Development Institute, Adelaide

Fry B, Silva SR, Kendall C, Anderson RK (2002) Oxygen isotope corrections for online $\delta^{34} \mathrm{~S}$ analysis. Rapid Commun Mass Spectr 16:854-858

Gray CA, McElligott DJ, Chick RC (1996) Intra- and interestuary differences in assemblages of fishes associated with shallow seagrass and bare sand. Mar Freshw Res 47:723-735

Guest M, Connolly RM, Loneragan NR (2004). Within and among-site variability in $\delta^{13} \mathrm{C}$ and $\delta^{15} \mathrm{~N}$ for three estuarine producers, Sporobolus virginicus, Zostera capricorni, and epiphytes of Z. capricorni. Aquat Bot 79:87-94

Hyndes GA, Potter IC (1997) Age, growth and reproduction of Sillago schomburgkii in south-western Australian, nearshore waters and comparisons of life history styles of a suite of Sillago species. Environ Biol Fish 49:435-447 Hyndes GA, Platell ME, Potter IC (1997) Relationships between diet and body size, mouth morphology, habitat and movements of six sillaginid species in coastal waters: implications for resource partitioning. Mar Biol 128:585-598

Jennings S, Renones O, Morales-Nin B, Polunin NVC, Moranta J, Coll J (1997) Spatial variation in the ${ }^{15} \mathrm{~N}$ and ${ }^{13} \mathrm{C}$ stable isotope composition of plants, invertebrates and fishes on Mediterranean reefs: implications for the study of trophic pathways. Mar Ecol Prog Ser 146:109-116

Kailola P, Williams M, Stewart P, Reichelt R, McNee A, Grieve C (1993) Australia's fisheries resources. Bureau of Resource Sciences, Brisbane

Kitting CL, Fry B, Morgan MD (1984) Detection of inconspicuous epiphytic algae supporting food webs in seagrass meadows. Oecologia 62:145-149

Klumpp DW, Nichols PD (1983) A study of food chains in seagrass communities II. Food of the rock flathead, Platycephalus laevigatus Cuvier, a major predator in a Posidonia australis seagrass bed. Aust J Mar Freshw Res 34:745-754

Kneib RT (2000) Saltmarsh ecoscapes and production transfers by estuarine nekton in the southeastern United States. In: Weinstein MP, Kreeger DA (eds) Concepts and controversies in tidal marsh ecology. Kluwer Academic, Dordrecht, p 267-292

Knight M, Tsolos A, Doonan A (2003) South Australian fisheries and aquaculture information and statistics report. Report No. 58, South Australian Research and Development Institute, Adelaide

Lee SY (1995) Mangrove outwelling-a review. Hydrobiologia 295:203-212

Lepoint G, Nyssen F, Gobert S, Dauby P, Bouquegneau J (2000) Relative impact of a seagrass bed and its adjacent epilithic algal community in consumer diets. Mar Biol 136:513-518

Loneragan NR, Bunn SE, Kellaway DM (1997) Are mangroves and seagrasses sources of organic carbon for penaeid prawns in a tropical Australian estuary? A multiple stable isotope study. Mar Biol 130:289-300

McCutchan J, Lewis W, Kendall C, McGrath C (2003) Variation in trophic shift for stable isotope ratios in carbon, nitrogen, and sulphur. Oikos 102:378-390

McGlennon D, Branden KL (1994) Comparison of catch and recreational anglers fishing on artificial reefs and natural seabed in Gulf St. Vincent, South Australia. Bull Mar Sci 55:510-523

Melville AJ, Connolly RM (2003) Spatial analysis of stable isotope data to determine primary sources of nutrition for fish. Oecologia 136:499-507

Middelburg JJ, Barranguet C, Boschker HTS, Herman PMJ, Moens T, Heip CHR (2000) The fate of intertidal microphytobenthos carbon: an in situ $\delta^{13} \mathrm{C}$-labeling study. Limnol Oceanogr 45:1224-1234

Moncreiff CA, Sullivan MJ (2001) Trophic importance of epiphytic algae in subtropical seagrass beds: evidence from multiple stable isotope analyses. Mar Ecol Prog Ser 215:93-106

Mutchler T, Sullivan MJ, Fry B (2004) Potential of ${ }^{14} \mathrm{~N}$ isotope enrichment to resolve ambiguities in coastal trophic relationships. Mar Ecol Prog Ser 266:27-33

Noye J (1984) Physical processes and pollution in the waters of Spencer Gulf. Mar Geol 61:197-220

Oakes JM, Connolly RM (2004) Causes of sulphur isotope variability in the seagrass, Zostera capricorni. J Exp Mar Biol Ecol 302:153-164

Odum EP (2000) Tidal marshes as outwelling/pulsing systems. In: Weinstein MP, Kreeger DA (eds) Concepts and 
controversies in tidal marsh ecology. Kluwer Academic, Dordrecht, p 3-7

Peterson BJ, Fry B (1987) Stable isotopes in ecosystem studies. Annu Rev Ecol Syst 18:293-320

Peterson BJ, Howarth RW (1987) Sulphur, carbon, and nitrogen isotopes used to trace organic matter flow in the salt-marsh estuaries of Sapelo Island, Georgia. Limnol Oceanogr 32:1195-1213

Phillips DL, Gregg JW (2003) Source partitioning using stable isotopes: coping with too many sources. Oecologia 136: 261-269

Polis G, Anderson W, Holt R (1997) Toward an integration of landscape and food web ecology: the dynamics of spatially subsidized food webs. Annu Rev Ecol Syst 28:289-316

Potter IC, Hyndes GA (1999) Characteristics of the ichthyofaunas of southwestern Australian estuaries, including comparisons with holarctic estuaries and estuaries elsewhere in temperate Australia: a review. Aust J Ecol 24:395-421

Editorial responsibility: Otto Kinne (Editor-in-Chief), Oldendorf/Luhe, Germany
Robertson AI, Lenanton RCJ (1984) Fish community structure and food chain dynamics in the surf-zone of sandy beaches: the role of detached macrophyte detritus. J Exp Mar Biol Ecol 84:265-283

Stevens T (2002) Rigor and representativeness in marine protected area design. Coast Manag 30:237-248

Vander Zanden MJ, Rasmussen JB (2001) Variation in delta $\mathrm{N}-15$ and delta C-13 trophic fractionation: implications for aquatic food web studies. Limnol Oceanogr 46:2061-2066

Vizzini S, Sara G, Michener RH, Mazzola A (2002) The role and contribution of the seagrass Posidonia oceanica organic matter for secondary consumers as revealed by carbon and nitrogen stable isotope analysis. Acta Oecol 23:277-285

Winning MA, Connolly RM, Loneragan NR, Bunn SE (1999) ${ }^{15} \mathrm{~N}$ enrichment as a method of separating the isotopic signatures of seagrass and its epiphytes for food web analysis. Mar Ecol Prog Ser 189:289-294

Submitted: March 30, 2004; Accepted: July 20, 2004 Proofs received from author(s): January 19, 2005 